\title{
STRATEGI PRODUKSI, PEMASARAN, DAN PENGELOLAAN SDM NET.TV DALAM MENGHADAPI PERSAINGAN INDUSTRI TELEVISI
}

\author{
Joni Arman Hamid ${ }^{(1)}$ \\ Prodi Broadcasting, Fakultas Ilmu Komunikasi (FIKOM) Universitas Mercu Buana. \\ Jln. Meruya Selatan, Kembangan Jakarta Barat. 11650.
}

Email: (1) joni arman@yahoo.com

\begin{abstract}
Competition in the television industry in Indonesia is experiencing rapid development, especially now that the era of media convergence is expanding. NET TV as one of the national private companies is present with strategies, marketing, and Human Resources (HR) development by combining conventional methods with new ways. The writing of this paper is on program development concepts which include: pre-production, production, and evaluation. For marketing strategy, NET.TV reduces to Kotler and Keller who see marketing strategies starting from the target audience, consumer classification, and target market determination. This journal writing uses a qualitative approach, with a constructivist paradigm, and uses the case study method. The data was obtained through literature review, observation, and in-depth interviews with editors, HRD, Marketing, and NET.TV Head of Production. The results showed that NET.TV followed production procedures by relying on the creativity of human resources without deviating from the technical rules of production. Likewise, related to marketing, they utilize social media with human resource creativity.
\end{abstract}

Keywords: production strategy, marketing strategy, human resources, television industry, NET TV.

\section{PENDAHULUAN}

Salah satu ciri khas kehidupan masyarakat hari ini adalah tingginya tingkat mobilitas dan kebutuhan masyarakat akan informasi. Televisi sebagai sebuah media dan bagian dari kemajuan teknologi, hari ini tidak dapat dipisahkan dari kehidupan masyarakat. Bagaimana tidak, televisi sampai hari ini masih menjadi media utama dalam memenuhi kebutuhan informasi masyarakat, walaupun konvergensi media semakin meluas dengan terpaan internet. Tidak hanya sebagai media informasi, televisi menjadi media dan sarana hiburan yang murah bagi keluarga Indonesia.

Salah satu media yang mampu memenuhi kebutuhan masyarakat tersebut (kebutuhan akan informasi dan hiburan) adalah televisi. Televisi banyak digemari oleh masyarakat karena penggunaannya yang mudah, cepat, dan tidak membosankan karena televisi tidak hanya menyajikan gambar dan tulisan tetapi juga dengan suara (Azwar, dkk 2019). 
NET.TV sebagai stasiun televisi paling muda dari dari 12 stasiun televisi swasta nasional yang ada mempunyai tampilan yang berbeda dari pendahulunya. Menurut pengamatan dari penulis ada kekhasan dan keperbedaan dari tampilan program NET.TV tersebut. Dilihat dari data selama NET.TV siaran, NET.TV mampu bersaing di tingkat Asia. NET.TV nominasi 8 kategori yang dinilai oleh penyelenggara (penyelenggara siaran televisi tingkat asia di Bangkok 2014). NET.TV juga mampu menjadi pesaing yang handal dalam industrialisasi pertelevisian di tingkat Asian Tenggara, setidaknya menjadi televisi berperingkat ketiga yang memiliki tingkat share paling tinggi (Assen Nielsen Institute 2014).

Data di atas menggambarkan bagaimana NET.TV mampu bersaing dengan stasiun televisi yang telah ada lebih dulu, mengingat NET.TV baru berusia muda. Beberapa hal yang menjadi catatan penulis dalam melihat bagaimana strategi NET.TV bersaing adalah NET.TV mampu mengemas program-program siarannya secara berbeda dan menampilkan beberapa poin seperti keterlibatan masyarakat dalam program citizen jounalism dan program yang melibatkan institusi kepolisian dalam program 86 Siap.

Untuk menciptakan sebuah program yang berkualitas dibutuhkan para pekerja dan pemikir (sumber daya manusia) yang cerdas dalam melihat segmentasi. Hal ini diartikan bahwa pembangunan sumber daya manusia juga menjadi strategi NET.TV dalam menghadapi persaingan antar industri televisi di Indonesia. Persaingan industri pertelevisian tentunya membawa dampak yang positif apabila masyarakat Indonesia secara kualitas mampu bersaing. Hal ini juga terjadi pada para pekerja media atau para crew stasiun televisi - NET.TV.

NET.TV sebagai anggota kelompok industri media saat ini memerlukan kemampuan pengelolaan yang baik dan benar. Baik pengelolaan bisnis, pengeloalan sumber daya manusia, serta pengembangan aspek kreatifitas dari semua unsur dalam Industri media televisi tersebut. Maraknya industri media televisi saat ini memberikan peluang yang positif untuk peluang bagi SDM dan para pembuat program. Persaingan antar industri di Indonesia akan terjadi dan sedang terjadi saat ini. Bebagai pengembangan program saling bersaing satu stasiun televisi dengan stasiun televisi lainnya.

Daerah Indonesia yang terbentang dari Sabang sampai Merauke merupakan daerah yang mudah dimasuki oleh negara sekitar karena sepanjang daerah Indonesia terletak negaranegara ASEAN. Jumlah Penduduk yang banyak, tentu memiliki selera yang beragam. Ini merupakan pasar yang empuk untuk Industri Media Televisi serta Industri lainnya yang memanfaatkan media televisi.) 
Fokus penulisan jurnal ini adalah bagaimana strategi produksi, strategi pemasaran, dan strategi pengelolaan SDM NET.TV dalam persaingan industri televisi di Indonesia. Sementara itu tujuan penulisan jurnal ini adalah untuk memahami dan menjelaskan stategi produksi, strategi pemasaran, dan strategi pengelolaan SDM NET.TV dalam menghadapi persaingan industri televisi di Indonesia.

\subsection{Televisi Sebagai Media Komunikasi Massa}

Komunikasi merupakan satu hal yang mendasar dalam kehidupan manusia. Carl Hovland mendefinisikan komunikasi sebagai "The process by which an individual (the communicator) transmits stimuli (usually verbal symbols) to modify behavior of the individuals (communicatess).” (McQuail 2000). Proses dimana seorang komunikator menyampaikan rangsangan-rangsangan biasanya lambang-lambang dalam bentuk kata-kata untuk merubah tingkah laku komunikan (Effendy 1993).

Televisi siaran merupakan media komunikasi massa karena memenuhi unsur-unsur yang terdiri dari sumber (source), pesan (message), saluran (channel), penerima (receiver) serta efek (effect). (Wiriyanto 2003). Pada saat ini televisi merupakan salah satu media komunikasi yang banyak dibutuhkan masyarakat karena televisi memiliki sifat media yang khas sebagai media pandang dengar (audio-visual) sifat ini menjadikan keunggulan media televisi mampu menyampaikan pesan yang lebih hidup. Segala informasi seperti isu sosial politik, ekonomi, budaya, hukum, kriminalitas, olah raga sampai dengan masalah gosip para public figure, kuis, permainan (games) semuanya ditayangkan di media televisi dengan beragam kreasi pengemasan program acaranya.

\section{Industri Televisi Indonesia Dalam Perspektif Ekonomi Politik}

Seiring perkembangan teknologi informasi dan globalisasi, industri pertelevisian juga mengalami perubahan yang signifikan. Perubahan tersebut terlihat jelas pada aspek struktur, mekanisme kerja dan operasional maupun content media massa. Hal ini, pada akhirnya mendesak berbagai institusi media untuk mengikuti pola-pola persaingan bisnis industri media agar tetap bertahan. Ketatnya iklim persaingan dalam industri pertelevisian di Indonesia pada akhirnya berpengaruh pada makin kuatnya nilai-nilai kepentingan ekonomi (profit) terhadap nilai-nilai idealisme media.

Tinjauan di atas membawa penulis pada pentingnya sebuah strategi untuk bersaing dalam industri pertelevisian. Ada beberapa hal yang mesti diperhatikan dalam konteks ini, yaitu bagaiamana strategi managmet sebuah perusahaan media (NET.TV) dalam 
memproduksi program, bagaimana konsep pemesaran yang diterapkan oleh perusahaan media dan bagaiamana perusahaan media mengelola sumber daya manusianya. Ketiga hal ini bersinergi dengan apa yang menjadi fokus penulis dalam penelitian ini.

\section{Management Produksi Program Industri Pertelevisian}

Managemen berasal dari bahasa Inggris yaitu kata manage-ment turunan dari kata to manage yang artinya mengurus atau tata laksana atau ketatalaksanaan. Sehingga managemen berarti bagaimana cara mengatur orang, membimbing dan memimpin semua orang yang menjadi pembantunya agar usaha yang sedang digarap mencapai tujuan yang telah ditetapkan sebelumnya. Menurut George R Terry, fungsi managemen meliputi POAC, yaitu planning (perencanaan), organizing (pengorganisasian), actuating (penggerakan) dan controlling (pengawasan) (Morrisan 2008).

Produksi di NET.TV mengikuti alur besar seperti yang disampaikan Morissan yaitu proses perencanaan (pra produksi), proses eksekusi siaran (produksi) dan proses pasca produksi sendiri.

1) Perencanaan (Pra Produksi)

2) Tahap pelaksanaan produksi

3) Pengawasan dan Evaluasi (Pasca Produksi)

Secara garis besar produksi televisi adalah suatu proses kreatif yang melibatkan penggunaan peralatan-peralatan yang rumit dan koordinasi sekelompok individu yang mempunyai kepekaan estetis dan kemampuan teknis untuk mengkomunikasikan pikiran dan perasaan kepada penonton. Di bagian manapun kita berperan, harus di sadari bahwa proses produksi program televisi adalah suatu team work.

2. Konsep Pemasaran Dalam Industri Pertelevisian

Konsep pemasaran dalam industri pertelevisian pada dasarnya mengikuti apa yang disampaikan Pringle dkk (dalam Morrisan 2013). Menurutnya pemasaran industri penyiaran memiliki tanggungjawab antara lain: pertama, menjual waktu siaran kepada pemasang iklan. Kedua, menyediakan sarana di mana pemasang iklan dapat mencapai target audiennya dengan biaya kompetitif. Ketiga, menghasilkan pendapatan yang cukup agar stasiun televisi penyiaran dapat beroperasi secara kompetitif. Keempat, menghasilkan keuntungan bagi pemilik stasiun televisi.

3. Pengelolaan dan Pengembangan Sumber Daya Manusia Dalam Indsutri Pertelevisian

Pengelolaan sumber daya manusia dalam industri media (televisi) memiliki keterkaitan dan pengaruh yang signifikan terhadap kinerja organisasional media dengan cara 
menciptakan nilai atau menggunakan keahlian sumber daya manusia yang berkaitan dengan praktek manajemen dan sasarannya cukup luas, serta tidak terbatas hanya pada karyawan oiperasional semata, namun juga meliputi tingkatan manajerial.

Untuk menyederhanakan alur penelitian ini, berikut penulis menggambarkannya Bagan Kerangka Pemikiran sebagai berikut ini:

\section{Gambar: Skema Penulisan Jurnal}

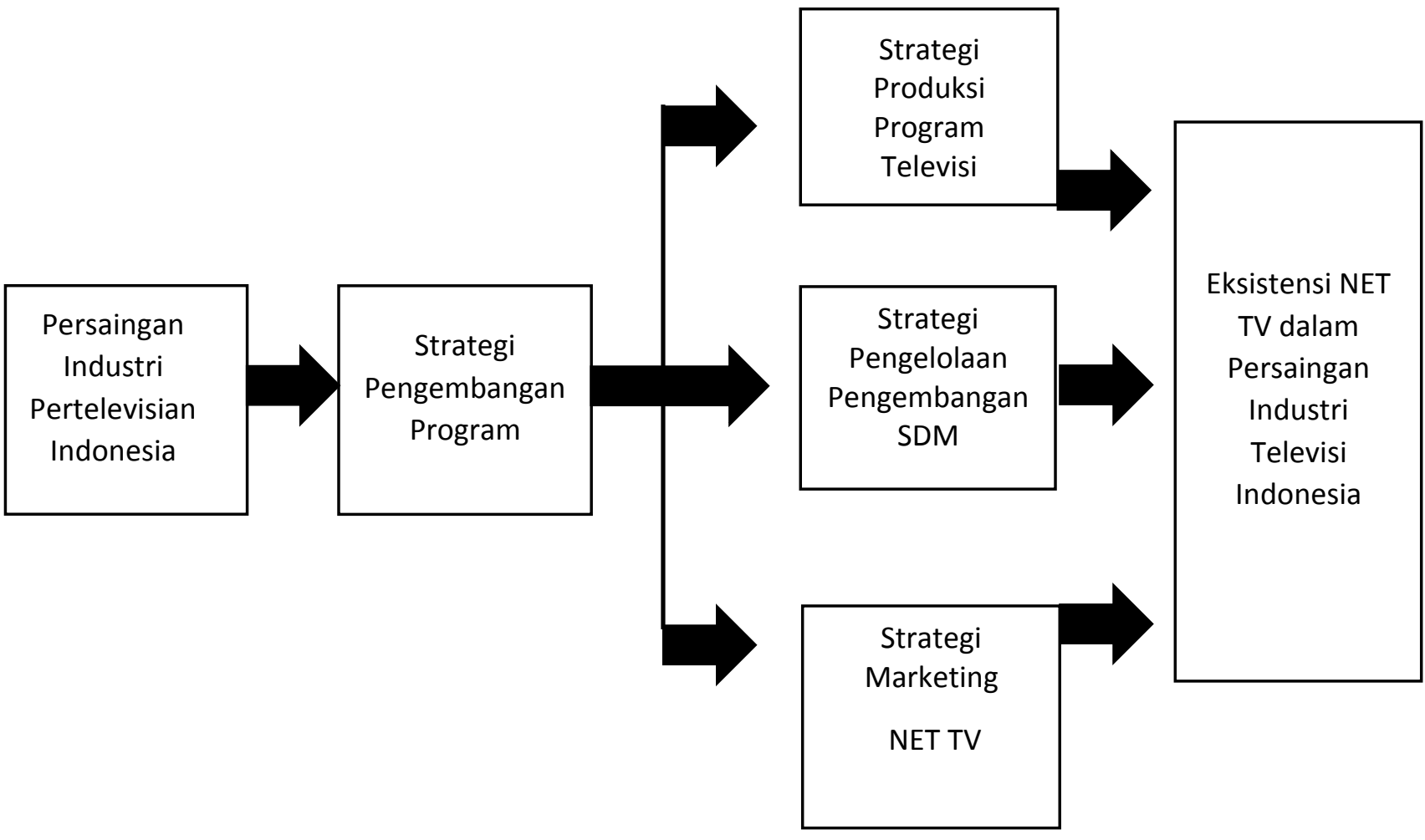

\section{METODE}

Penelitian ini menggunakan pendekatan kualitatif dengan paradigma konstruktivis. Metode penelitian menggunakan studi kasus, dimana peneliti mengutamakan kajian kepustakaan untuk mendapatkan data awal. Setelah itu peneliti melakukan observasi untuk memahami secara utuh bagaimana proses produksi, pemasaran, dan pengelolaan Sumber Daya Manusia (SDM) di NET.TV. Penelitian ini adalah penelitian deskriptif dengan memaparkan temuan-temuan selama proses penelitian. Ritzer dan Goodman, (2012) menyampaikanuntuk menganalisis data kualitatif, peneliti melakukan inventarisasi data, kemudian membuat kategorisasinya, melakukan penafsiran data dan terakhir menarik kesimpulan atas pertanyaan-pertanyaan yang diajukan dalam rumusan masalah dan tujuan. 


\section{HASIL DAN PEMBAHASAN}

News And Entertaiment Television (selanjutnya ditulis NET.TV) adalah sebuah televisi swasta nasional di Indonesia. NET.TV resmi mengudara di Indonesia pada 26 Mei 2013. NET.TV memiliki slogan "Revolusi Media". Secara organisasi perusahaan NET.TV merupakan bagian dari kelompok usaha Indika Group di bawah bendera Indika Energy Tbk. Kelompok usaha ini merupakan perusahaan yang bergerak di bidang usaha Event Organizer, Promotor, Broadcast Equipment, Production House, dan Radio.

Jadwal acara televisi di Indonesia dewasa ini memang sangat variatif. Walaupun akhir-akhir ini dihiasi oleh berbagai program asing yang justru mendominasi beberapa stasiun televisi nasional, namun beberapa stasiun televisi mulai menunjukkan kreatifitas baru dengan program-program yang lebih menarik dan edukatif. Tidak hanya konsisten dengan apa yang diusungnya 'Televisi Masa Kini', NETTV betul-betul hadir 'unjuk gigi' menyajikan suguhan tayangan-tayangan hiburan yang menarik, tidak murahan, elegan, dan tentunyasesuai dengan etika penyiaran.NETTVingin memberikan alternatif hiburan yang berkualitas di Indonesia dengan memberi sesuatu yang berbeda. Kekonsistenan NETTV menghadirkan acara-acara hiburan yang bermutu dan menghibur tadi, tidak sekedar menghibur, tetapi disisi lain memberikan edukasi dan pesan moral (Azwar, dkk 2019)

NET.TV sebagai stasiun televisi paling muda dari 12 stasiun televisi swasta nasional yang ada di Indonesia, mempunyai tampilan yang berbeda dari televisi-televisi pendahulunya. Perbedaan itu baik dari sisi tampilan maupun dari sisi isi siarannya. Tampilan NET.TV lebih cenderung menyasar penonton muda. Isi atau kontennya lebih inspiratif dan kreatif.

NET.TV secara kelembagaan memang hadir berbeda dibanding televisi lainnya. Hal itu tidak membuat ia ditinggallan penonton malah mendapat tempat di hati masyarakat. Menurut pengamatan penulis ada kekhasan dan perbedaan dari tampilan program NET.TV tersebut. Dilihat dari data selama NET.TV siaran, NET.TV mampu bersaing di tingkat nasional bahkan di tingkat Asia. NET.TV merupakan televisi yang mendapat nominasi dari 8 kategori yang dinilai oleh penyelenggara (penyelenggara siaran TV tingkat asia di Bangkok 2014). NET.TV juga mampu menjadi pesaing yang handal dalam industri pertelevisian di tingkat Asia Tenggara. Setidaknya NET.TV menjadi televisi yang memiliki peringkat ketiga yang dengan tingkat share paling tinggi di Indonesia (Assen Nielsen Institute 2014). 
NET.TV mampu bersaing dengan stasiun televisi yang telah ada lebih dulu, mengingat NET.TV baru berusia beberapa tahun. Beberapa hal yang menjadi catatan penulis dalam melihat bagaimana strategi NET.TV bersaing adalah NET.TV mampu mengemas program-program siarannya. Target NET.TV yaitu menyasar anak-anak muda sebagai target utama dengan meluncurkan program-program seperti musik, kuis dan talk show dimana dalam program tersebut menampilkan bintang tamu yang sangat jarang muncul di stasiun TV lainnya. Untuk menciptakan sebuah program yang berkualitas dibutuhkan para pekerja dan pemikir yang cerdas (Sumber Daya Manusia) dalam melihat segmentasi pasar. Hal ini diartikan bahwa pembangunan sumber daya manusia juga menjadi strategi NET.TV dalam meningkatkan daya saingnya pada TV nasional.

\section{STRATEGI PRODUKSI PROGRAM SIARAN NET.TV}

Berdasarkan penelitian yang penulis lakukan, strategi produksi yang dilakukan NET.TV, dapat dilihat bahwa NET.TV memiliki strategi yang berbeda-beda pada setiap programnya. Walaupun masing-masing program memiliki perbedaan dalam strategi produksi ataupun pemasarannya, akan tetapi secara garis besar, semua program NET.TV memiliki alur yang sama. Alur itu adalah setiap produksi program akan melalui perencanaan, pengorganisasian, produksi, dan pengawasan. Dengan alur itu maka NET.TV menghasilkan program yang berbeda.

Dari penjelasan tersebut dapat dilihat bahwa NET.TV hadir dengan memadukan berbagai SDM untuk menghasilkan program yang menarik. Hal ini berpengaruh terhadap proses perencanaan (pra produksi), proses eksekusi siaran (produksi) dan proses pasca produksi sendiri. Untuk lebih jelas, berikut ini akan penulis uraikan proses perencanaan, produksi dan pasca produksi di NET.TV.

\section{Perencanaan (Pra Produksi)}

Perencanaan di NET.TV pada dasarnya mengikuti apa yang disampaikan, Morissan (2008) bahwa perencanaan program biasanya menjadi tanggung jawab manajemen puncak stasiun penyiaran. Dalam perencanaan program ini, terdapat faktor-faktor yang memengaruhi dalam penentuan program, di antaranya yaitu pengelola atau pemilik stasiun, audiens, pemasang iklan atau sponsor, serta regulator. NET.TV memiliki bagian khusus dalam perencanaan program yang bertugas merencanakan program yang akan mereka sajikan. 


\section{Tahap pelaksanaan produksi}

Dalam industri televisi sebagaimana yang dilakukan NET.TV, produksi merupakan implementasi dari apa yang sudah direncanakan dari awal. Berdasarkan pengamatan peneliti, produksi yang dilaksanakan di NET.TV sesuai dengan apa yang sudah direncanakan. Walaupun kemudian dalam prakteknya terjadi beberapa perubahan karena sesuatu dan lain hal. Perubahan itu tidak mengubah esensi program sebagaimana yang sudah direncanakan. Di NET.TV konsep yang telah disiapkan oleh tim kreative akan dieksekusi dengan baik, walaupun dalam pelaksanaannya crew atau host boleh berimprovisasi. Akan tetapi improvisasi yang dilakukan crew tidak boleh jauh melenceng dari apa yang sudah direncanakan.

\section{Pengawasan dan Evaluasi (Pasca Produksi)}

Pada tahap pengawasan dan evaluasi NET.TV juga memberi perhatian khusus. Tahap ini dilakukan pada pasca produksi yaitu melakukan penggabungan gambar untuk menjadi satu kesatuan gambaran yang utuh sesuai dengan rundown awal. Walaupun ada beberapa hal yang dianggap kurang efektif dalam pengambilan gambar satu segmen dengan durasi 30 menit setelah itu saat editing harus ada pemotongan durasi dan akhirnya banyak yang terbuang.

Dari penjelasan di atas dapat dilihat bahwa selama dua tahun NET.TV sudah mencapai target iklan yang mereka tetapkan. Bahkan dari sisi penjualan NET.TV sudah melewati Metro TV dan sedang bersaing dengan TV One. NET.TV yakin dengan penggarapan yang lebih baik bisa melewati TV One. Langkah-langkah itu sudah dilewati oleh NET.TV dan ditargetkan pada tahun ketiga hal itu akan tercapai. Baik target program maupun penjualan.

NET.TV bisa melampaui Metro TV dan bersaing dengan TV One karena NET.TV memiliki tim program yang merupakan perpaduan dari program itu sendiri dan produksi, dan program berita (news). Hal ini digabung menjadi satu karena NET.TV beranggapan bahwa bagian program lah yang membuat program tersebut. Artinya jangan sampai yang membuat program tidak tahu kesulitan yang terjadi di lapangan. Selama ini programing terkesan orangorang yang hebat dalam merumuskan teori, tetapi mentah pada apilikasi. Dengan menggabungkan dengan bagian produksi dan berita, NET.TV ingin mematahkan anggapan itu. 


\section{Program yang Baik Menurut NET.TV}

Program yang baik adalah program yang memenuhi syarat-syarat tertentu. Syarat itu ditetapkan NET.TV adalahpertama program yang bagus secara ide/gagasan. Ide atau gagasan itu juga bermacam-macam, ada ide yang asli dari tim kreatif ada juga yang diadopsi dari luar atau program lain yang sudah ada atau sudah diproduksi televisi luar negeri. Contohnya Program 86 itu mengadopsi program Corps di Amerika Serikat.

Kedua ide tersebut sudah ada atau tidak di televisi lain, atau televisi kompetitor. Kalau sudah ada biasanya tidak diproduksi karena jelas akan kalah saing dengan televisi yang sudah lama. NET.TV mementingkan kebaruan dalam menerima konsep yang ditawarkan. Kebaruan ini bukan berarti benar-benar baru, tetapi setidaknya program yang dibuat tidak mirip dengan program yang sudah ada di televisi di dalam negeri (Indonesia). Hal ini untuk menghindari penonton yang bosan terhadap program yang dibuat.

Ketiga NET.TV juga memperhatikan apakah ide/gagasan yang ditawarkan itu bisa dieksekusi dengan SDM yang ada atau tidak. NET.TV akan mengukur kemampuan untuk membuat sebuah program yang baik. Bisa jadi sebuah program yang ditawarkan tim kreatif itu program yang bagus, atau program yang sukses di luar negeri, tetapi jika SDM dan kemampuan finansial atau bahkan kemampuan teknologi terbatas, program yang bagus itu juga tidak bisa dieksekusi.

\section{STRATEGI PEMASARAN NET.TV}

Berdasarkan wawancara dengan Deputi VP Sales dan Marketing NET.TV, Ade W. Setiawan dan dielaborasi dengan data-data lain, maka strategi pemasaran NET.TV dapat diuraikan bahwa strategi yang digunakan oleh sales marketing adalah dengan melihat ratting yang belum dicukupi untuk standar berkompetisi dengan TV-TV lain.

NET.TV memanfaatkan keunggulan teknologi informasi untuk menutupi mereka sebagai pemain baru dalam dunia televisi. NET.TV memanfaatkan media sosial untuk memberi nilai tambah pada program mereka. Media yang dipakai seperti Youtube Chanel, dari viewer di Youtube Chanel itu NET.TV bisa meyakinkan klien dalam pemasaran program mereka. Selain itu mereka juga bisa memanfaatkan nilai tambah dari teresterialnya ditambah digital.

Hal lain terkait dalam pemasaran yang dilakukan NET.TV adalah menjual value edit after activation, NET.TV memberi layanan sekaligus dua hal kepada klient. Hal ini bisa 
dilakukan karena di NET.TV bagian kreatif terhubung erat dengan sales marketing. Lebih jauh dari hasil wawancara tersebut dapat dilihat bahwa yang dilakukan oleh NET.TV adalah Pertama dengan cara menjual value editing yang lain. Kedua NET.TV juga menjual conversation di sosial media contohnya di twitter. Ketiga NET.TV juga menjual value edit erupa after activation.

Peneliti memahami bahwa apa yang dilakukan NET.TV ini merupakan terobosan yang bermanfaat untuk client. Dulu client antara program on air dan off air harus menemui dua company yang berbeda, tapi sekarang dengan terobosan yang dilakukan NET.TV client akan bisa melakukan pada satu tempat saja. Jika di televisi lain selain NET.TV bicara soal kreatif harus mengundang produksi dan news atau pihak-pihak terkait internal, maka di NET.TV pembicaraan soal kreatif program sudah ada di bawah sales marketing.

\section{Konsep Komunikasi Pemasaran}

Jika dianalisis berdasarkan komunikasi pemasaran yang mempunyai tujuan sebagaimana diuraikan di atas, NET.TV sudah melakukan hal tersebut:

1) Menyebarluaskan informasi (komunikasi informatif)

NET.TV sudah melakukan penyebarluasan informasi melalui media-media baru. Mereka melakukan pemasaran mulai dari yang konvensional sampai yang moderen. Pemasaran konvensional tetap menggunakan penawaran kepada client. Sementara itu pemasaran moderen mereka telah menyebarluaskan informasi melalui media sosial. Bahkan mereke membuat terobosan dengan menjual percakapan di media sosial kepada client untuk mendampingi rating.

2) Mengingatkan audien untuk melakukan pembelian ulang (komunikasi mengingat-kan kembali)

NET.TV sangat intens daam mengingatkan audience untuk melakukan pembelian ulang program. Contohnya saat mereka menawarkan spot iklan pada perusahaan tertentu, hal itu tidak ditawarkan sekali saja, tetapi dengan metode berbeda-beda, baik presentasi maupun hal lainnya.

3) Mempengaruhi audiens untuk melakukan pembelian atau menarik konsumen pesaing agar beralih merek (komunikasi persuasif) 
NET.TV mempengaruhi pengiklan tidak hanya dengan presentasi program dan membuat penawaran yang baik. Mereka tidak hanya menyampaikan rating program yang sudah ada, tetapi mereka mendampingi dengan item-item lainnya seperti percakapan di media sosial. Bahkan mereka juga menawarkan acara on air yang menarik bagi calon pengiklan.

4) Meningkatkan/melakukan penjualan (Komunikasi penjualan)

Dengan cara-cara tersebut otomatis penjualan akan semakin meningkat. NET.TV berkomitmen menghadirkan program-program yang secara isi adalah program yang kreatif kepada calon pengiklan. Penjualan ini sejauh ini berjalan efektif dilihat dari pesatnya perkembangan NET.TV dari sisi penjualan spot iklan mereka.

\section{STRATEgI PENGELOLAAN DAN PENGEMBANGAN SUMBER DAYA MANUSIA NET.TV}

Berdasarkan keterangan Hery Kustanto Vice President Corporate Service NET.TV terungkap bahwa dari sisi Sumber Daya Manusia (SDM), pemasaran NET.TV sudah direncanakan dari awal dengan matang. NET.TV memiliki satu tim yang memang "diambil" dari beberapa televisi yang sudah matang.

Untuk memenuhi kebutuhan SDM di NET.TV, dilakukan seleksi yang cukup ketat. Walaupun karyawan yang direkrut adalah karyawan berpengalaman yang pernah berkarir di televisi-televisi swasta lainnya, tetap saja seleksi dilakukan dengan ketat. Hal ini dilakukan untuk memenuhi target SDM yang benar-benar menguasai bidangnya masing-masing.

Dilihat dari kaderisasi internal itu, karyawan senior akan menjadi acuan bagi juniornya. SDM senior ini akan mengajarkan ke bawahannya (junior). Mereka belajar cara menghadapi klient, cara membaca data, cara minta data dan apa saja yang dibutuhkan saat menghadap klient.

Karena SDM berasal dari berbagai macam latar belakang, aplikasi yang dilakukan itu adalah item jualan yang mereka jual. Jika mereka berasal dari stasiun televisi yang lama, maka pada saat masuk ke NET.TV mereka harus mengubah cara pandang mereka dalam memasarkan produk. Hal ini terjadi karena pertama pada televisi lain barangkali mereka hanya terpaku pada rating dalam memasarkan produk, sementara NET.TV menerapkan hal 
yang berbeda. Sebagaimana dijelaskan di atas, NET.TV menerapkan kombinasi rating dan media sosial.

Keduasales NET.TV harus berpikir lebih cerdas, bahwa yang mereka tawarkan itu adalah kreativitas program, bukan hanya rating dan jam tayang. Jika kreativitasnya bagus, maka cocok dengan produk-produk perusahaan tertentu. Visi misinya harus bisa menjual sesuai arahan managemen. NET.TV ini merupakan televisi flatform. Flatform yang ada itu harus bisa diisi. Selain itu NET.TV secara kualitas kreatif harus lebih kuat. Oleh sebab itu NET.TV sangat mengandalkan tim kreatif sendiri.

Ketiga karena NET.TV sangat mengandalkan tim kreatif, maka saat rekrutment SDM, mereka sangat mementingkan orang-orang yang kreatif. Persoalan kreativitas ini tidak hanya pada tim kreatif secara sebenarnya, akan tetapi semua SDM yang direkrut itu harus kreatif, bahkan sales sekalipun haruslah sales yang kreatif. Untuk hal ini yang dilakukan NET.TV misalnya memberi tantangan kasus kepada calon karyawan, kemudian meminta mereka memberi jalan keluar yang baik dengan sentuhan kreatifitas mereka. Mereka-mereka yang paling kreatif lah yang akan diterima sebagai karyawan.

\section{KESIMPULAN}

Berdasarkan hasil pengamatan peneliti, NET.TV memiliki gaya dan strategi yang berbeda dalam memproduksi program. Tentunya dengan tujuan untuk merebut pangsa pasar satasiun TV yang sudah terlebih dulu hadir di Indonesia. NET.TV secara kelembagaan memang hadir berbeda dibanding televisi lainnya. Hal itu tidak membuat ia ditinggallan penonton malah mendapat tempat di hati masyarakat. NET.TV mampu bersaing di tingkat nasional bahkan di tingkat Asia. Kesimpulan penelitian ini adalah:

1. Strategi produksi program siaran NET.TV memiliki strategi yang berbeda-beda pada setiap programnya. Walaupun masing-masing program memiliki perbedaan dalam strategi produksi ataupun pemasarannya, akan tetapi secara garis besar, semua program NET.TV memiliki alur yang sama. Alur itu adalah setiap produksi program akan melalui perencanaan, pengorganisasian, produksi, dan pengawasan. Dengan alur itu maka NET.TV menghasilkan program yang berbeda.

2. Strategi pemasaran NET.TV dengan melihat ratting yang belum dicukupi untuk standar berkompetisi dengan TV-TV lain. NET.TV memanfaatkan keunggulan 
teknologi informasi untuk menutupi mereka sebagai pemain baru dalam dunia televisi. NET.TV memanfaatkan media sosial untuk memberi nilai tambah pada program mereka. Media yang dipakai seperti Youtube Chanel, dari viewer di Youtube Chanel itu NET.TV bisa meyakinkan klien dalam pemasaran program mereka. Selain itu mereka juga bisa memanfaatkan nilai tambah dari teresterialnya ditambah digital.

3. Strategi pengelolaan dan pengembangan Sumber Daya Manusia NET.TV. Untuk memenuhi kebutuhan SDM di NET.TV, dilakukan seleksi yang cukup ketat. Walaupun karyawan yang direkrut adalah karyawan berpengalaman yang pernah berkarir di televisi-televisi swasta lainnya, tetap saja seleksi dilakukan dengan ketat. Hal ini dilakukan untuk memenuhi target SDM yang benar-benar menguasai bidangnya masing-masing.

Berdasarkan penelitian yang sudah dilakukan, maka peneliti menyarankan hal-hal sebagai berikut:

1. Dalam industri televisi tidak bisa dihilangkan hal-hal umum terkait strategi produksi siaran. Produksi program siaran NET.TV bisa menjadi acuan bagi industri televisi yang baru untuk bersaing dengan industri televisi yang sudah matang. Perlu perencanaan yang matang yang dilakukan dalam tahap pra produksi. Untuk menjaga kualitas tayangan, industri televisi harus berkomitmen bahwa dalam produksi, program tidak boleh terlalu diintervensi oleh sponsor. Untuk menjaga komitmen itu sebenarnya sudah dibuat sebuah sistem yang baku oleh managemen industri televisi.

Dalam tahap produksi perlu dilakukan dengan keseriusan dan mengandalkan sumber daya manusia yang kreatif. Orang-orang kreatif ini perlu diberi tempat untuk mengelola program-program yang tidak biasa. Sementara itu pada pengawasan dan evaluasi juga perlu diberi perhatian khusus.

2. Terkait strategi pemasaran perlu melihat ratting yang ada. Namun peneliti menyarankan agar rating tidak dijadikan begitu saja. Perlu ada terobosan yang tidak hanya menjadikan rating sebagai sumber utama dalam memasarkan produk. Perlu menempuh cara yang dilakukan NET.TV yaitu dengan memperhatikan alternatif lain seperti media sosial. Percakapan di media sosial bisa dijadikan "jualan" untuk mendaampingi rating. Hal ini bisa dilakukan agar rating tidak 
berdiri sendiri. Hal lain terkait dalam pemasaran yang dilakukan adalah menjual value edit after activation. Hal ini bisa dilakukan karena bagian kreatif terhubung erat dengan sales marketing.

3. Untuk memenuhi SDM di industri pertelevisian perlu memperhatikan strategi pengelolaan dan pengembangan Sumber Daya Manusia. Perlu dilakukan seleksi yang cukup ketat, walaupun karyawan yang direkrut adalah karyawan berpengalaman yang pernah berkarir di televisi-televisi swasta lainnya. Perlu adanya standar yang tinggi bagi SDM yang akan ditempatkan pada level tersebut.

\section{DAFTAR PUSTAKA}

Azwar, dkk. (2018) "Etika dalam Program Hiburan Televisi: Analisis Program Hiburan Waktu Indonesia Bercanda NET TV.” Journal of Digital Education, Communication, and Arts • Vol. 1 • No. 2• Sept2018 • E-ISSN:2614-6916| 97.

Azwar, dkk. (2018) "DampakSinetron Indonesia Terhadap Perilaku Masyarakat(Analisis Kasus: Sinetron Anak Langit di SCTV)" Journal of Digital Education, Communication, and Arts. Vol. 2, No. 2, September 2019, 89 -98E-ISSN: 2614-6916. Effendy, Onong Uchjana. (2003). Ilmu, Theori dan Filsafat Komunikasi. PT. Cipta Aditya Bakti. Bandung.

McQuails, Denis. (2000), Mass Communication Theories, Fourth Editions. Sage Publication, London. Mosco, Vincent. 1996, The Political Economy of Communication: Rethinking and Renewal, Sage Publication. London.

Morissan. (2008). Manajemen Media Penyiaran: Strategi Mengelola Radio dan Televisi. Kencana Prenada Media Group. Jakarta.

Ritzer, George and Douglas J.Goodman, (2012), Teori Sosiologi, Dari Teori Sosiologi Klasik Sampai Perkembangan Mutakhir Teori Sosiologi Postmodern. Kreasi Wacana.Bantul. Wiryanto. (2003). Teori Komunikasi Massa, PT. Grasindo, Jakarta. 